\title{
KONSEP NILAI EKONOMI TOTAL DAN \\ METODE PENILAIAN SUMBERDAYA HUTAN
}

\author{
Oleh /Bye: \\ Fitri Nurfatriani ${ }^{1)}$
}

\begin{abstract}
Forest resource produce some benefits, both tangible and intangible. Currently, those benefits still under valued causing over exploitation of certain forest benefits. The over exploitation will always happen, as long as some stake holders are still not aware to the value of forest benefits comperehensively, especially for the intangible benefit and non marketable forest product. Hence we need to do the valuation of all the forest benefits in order to understand all the forest benefits deeply. Many techniques and methods of natural resources valuation has been developing. After we know about all the value of forest benefits, it could be usefull for the decision maker to make the recomendation regarding the alocation of rarely natural resources and to distribute natural resource benefits fairly, to achieve maximum welfare of the people.The objective of the paper is to explain the concept of total economic value and some methods used to value forest resource and environment benefits.
\end{abstract}

Key words : forest, value, economic, benefit

\begin{abstract}
Abstrak
Sumberdaya hutan (SDH) menghasilkan manfaat yang menyeluruh baik manfaat tangible maupun manfaat intangible. Saat ini berbagai manfaat yang dihasilkan tersebut masih dinilai rendah, atau belum diketahui, sehingga menimbulkan terjadinya eksploitasi manfaat-manfaat yang telah dikenal dari SDH secara berlebihan. Hal tersebut disebabkan karena masih banyak pihak yang belum memahami konsep nilai dari berbagai manfaat SDH secara komperehensif, khususnya untuk manfaat intangible yang tidak memiliki harga pasar. Untuk memahami manfaat dari SDH tersebut perlu dilakukan penilaian terhadap semua manfaat yang dihasilkan SDH ini. Berbagai teknik dan metode penilaian ekonomi sumberdaya alam (SDA) telah dikembangkan untuk menghitung nilai ekonomi SDA yang memiliki harga pasar ataupun tidak. Dengan diketahuinya manfaat dari SDH ini maka hal tersebut dapat dijadikan rekomendasi bagi para pengambil kebijakan untuk mengalokasikan sumberdaya alam (SDA) yang semakin langka dan melakukan distribusi manfaat SDA yang adil, untuk mendapatkan total kesejahteraan masyarakat yang maksimal. Tulisan ini dibuat dengan tujuan untuk menjelaskan konsep nilai ekonomi total dan berbagai metode yang digunakan untuk menilai manfaat SDH dan lingkungan.
\end{abstract}

Kata kunci : hutan, nilai, ekonomi, manfaat 


\section{PENDAHULUAN}

Sumberdaya hutan (SDH) Indonesia menghasilkan berbagai manfaat yang dapat dirasakan pada tingkatan lokal, nasional, maupun global. Manfaat tersebut terdiri atas manfaat nyata yang terukur (tangible) berupa hasil hutan kayu, hasil hutan non kayu seperti rotan, bambu, damar dan lain-lain, serta manfaat tidak terukur (intangible) berupa manfaat perlindungan lingkungan, keragaman genetik dan lain-lain. Saat ini berbagai manfaat yang dihasilkan tersebut masih dinilai secara rendah sehingga menimbulkan terjadinya eksploitasi SDH yang berlebih. Hal tersebut disebabkan karena masih banyak pihak yang belum memahami nilai dari berbagai manfaat SDH secara komperehensif. Untuk memahami manfaat dari SDH tersebut perlu dilakukan penilaian terhadap semua manfaat yang dihasilkan SDH ini. Penilaian sendiri merupakan upaya untuk menentukan nilai atau manfaat dari suatu barang atau jasa untuk kepentingan manusia.

Dengan diketahuinya manfaat dari SDH ini maka hal tersebut dapat dijadikan rekomendasi bagi para pengambil kebijakan untuk mengalokasikan sumberdaya alam (SDA) yang semakin langka dan melakukan distribusi manfaat SDA yang adil. Terlebih dengan meningkatnya pertambahan penduduk saat ini yang menyebabkan timbulnya tekanan yang serius terhadap SDH, menyebabkan perlunya penyempurnaan pengelolaan SDA melalui penilaian akurat terhadap nilai ekonomi sumberdaya alam yang sesungguhnya.

Manfaat SDH sendiri tidak semuanya memiliki harga pasar, sehingga perlu digunakan pendekatan-pendekatan untuk mengkuantifikasi nilai ekonomi SDH dalam satuan moneter. Sebagai contoh manfaat hutan dalam menyerap karbon, dan manfaat ekologis serta lingkungan lainnya. Karena sifatnya yang non market tersebut menyebabkan banyak manfaat SDH belum dinilai secara memuaskan dalam perhitungan ekonomi. Tetapi saat ini, kepedulian akan pentingnya manfaat lingkungan semakin meningkat dengan melihat kondisi SDA yang semakin terdegradasi. Untuk itu dikembangkan berbagai metode dan teknik penilaian manfaat SDH, baik untuk manfaat SDH yang memiliki harga pasar ataupun tidak, dalam satuan moneter. Tulisan ini dibuat dengan tujuan untuk menjelaskan konsep nilai ekonomi total dan berbagai metode yang digunakan untuk menilai manfaat SDH dan lingkungan.

\section{METODE PENELITIAN}

Kajian ini merupakan hasil kajian desk study yaitu dengan melakukan pengumpulan data dengan cara studi literatur melalui pengumpulan berbagai referensi yang memuat berbagai konsep dan teori mengenai nilai ekonomi total sumber daya alam dan metode penilaian sumber daya hutan. Data yang terkumpul dianalisis secara kualitatif untuk mengklasifikasikan teori yang berkaitan dengan nilai ekonomi total dan metode penilaian sumber daya hutan.

\section{HASIL DAN PEMBAHASAN}

\section{A. Konsep Nilai Sumberdaya Hutan}

Nilai merupakan persepsi manusia tentang makna suatu objek (sumberdaya hutan) bagi individu tertentu pada tempat dan waktu tertentu. Oleh karena itu akan terjadi keragaman nilai sumberdaya hutan berdasarkan pada persepsi dan lokasi masyarakat yang berbeda-beda. Nilai sumberdaya hutan sendiri bersumber dari berbagai manfaat yang diperoleh masyarakat. Masyarakat yang menerima manfaat secara langsung akan memiliki persepsi yang positif terhadap nilai sumberdaya hutan, dan hal tersebut dapat ditunjukkan dengan tingginya nilai sumberdaya hutan tersebut. 
Hal tersebut mungkin berbeda dengan persepsi masyarakat yang tinggal jauh dari hutan dan tidak menerima manfaat secara langsung.

Nilai sumberdaya hutan ini dapat diklasifikasi berdasarkan beberapa kelompok. Davis dan Johnson (1987) mengklasifikasi nilai berdasarkan cara penilaian atau penentuan besar nilai dilakukan, yaitu : (a) nilai pasar, yaitu nilai yang ditetapkan melalui transaksi pasar, (b) nilai kegunaan, yaitu nilai yang diperoleh dari penggunaan sumberdaya tersebut oleh individu tertentu, dan (c) nilai sosial, yaitu nilai yang ditetapkan melalui peraturan, hukum, ataupun perwakilan masyarakat. Sedangkan Pearce (1992) dalam Munasinghe (1993) membuat klasifikasi nilai manfaat yang menggambarkan Nilai Ekonomi Total (Total Economic Value) berdasarkan cara atau proses manfaat tersebut diperoleh.

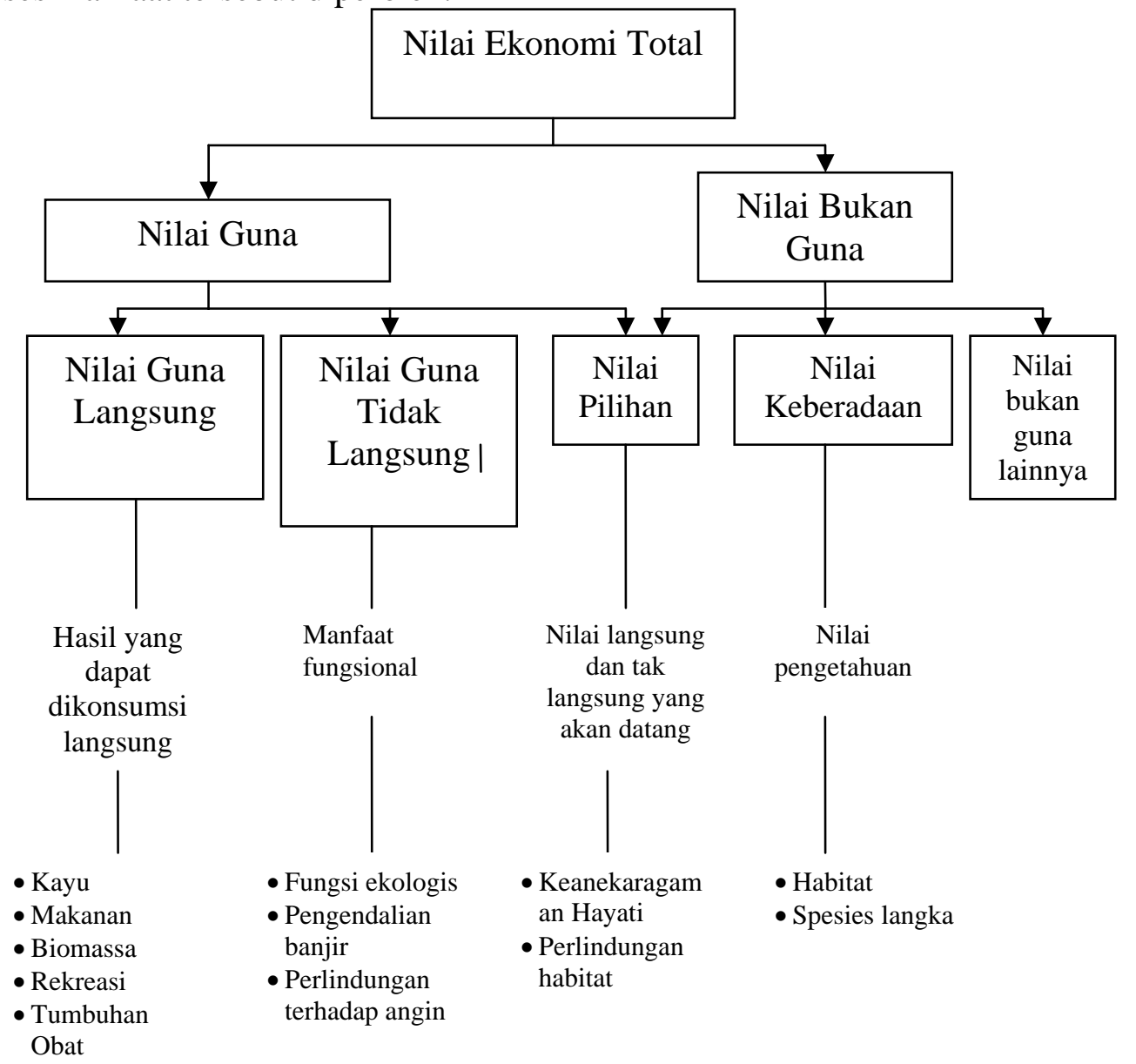

Gambar 1. Nilai ekonomi total dari sumberdaya hutan (Pearce, 1992 dalam Munasinghe 1993).

Figure 1. Total economic value of forest resources (Pearce, 1992 in Munasinghe 1993).

Nilai ekonomi total (NET) merupakan penjumlahan dari nilai guna langsung, nilai guna tidak langsung dan nilai non guna, dengan formulasi sebagai berikut (Pearce, 1992) :

NET = Nilai Guna Langsung + Nilai Guna Tidak Langsung + Nilai Pilihan + Nilai Keberadaan 
Nilai guna langsung merupakan nilai dari manfaat yang langsung dapat diambil dari SDH. Sebagai contoh manfaat penggunaan sumber daya hutan sebagai input untuk proses produksi atau sebagai barang konsumsi. Berbeda dengan nilai guna tidak langsung, yaitu nilai dari manfaat yang secara tidak langsung dirasakan manfaatnya, dan dapat berupa hal yang mendukung nilai guna langsung, seperti berbagai manfaat yang bersifat fungsional yaitu berbagai manfaat ekologis hutan. Sedangkan nilai bukan guna yaitu semua manfaat yang dihasilkan bukan dari hasil interaksi secara fisik antara hutan dan konsumen (pengguna).

Nilai pilihan, mengacu kepada nilai penggunaan langsung dan tidak langsung yang berpotensi dihasilkan di masa yang akan datang. Hal ini meliputi manfaat-manfaat sumber daya alam yang “disimpan atau dipertahankan” untuk kepentingan yang akan datang (sumber daya hutan yang disishkan untuk pemanenan yang akan datang), apabila terdapat ketidakpastian akan ketersediaan SDH tersebut, untuk pemanfaatan yang akan datang. Contoh lainnya adalah sumber daya genetik dari hutan tropis untuk kepentingan masa depan.

Sedangkan, nilai bukan guna meliputi manfaat yang tidak dapat diukur yang diturunkan dari keberadaan hutan di luar nilai guna langsung dan tidak langsung. Nilai bukan guna terdiri atas nilai keberadaan dan nilai warisan. Nilai keberadaan adalah nilai kepedulian seseorang akan keberadaan suatu SDH berupa nilai yang diberikan oleh masyarakat kepada kawasan hutan atas manfaat spiritual , estetika dan kultural. Sementara nilai warisan adalah nilai yang diberikan masyarakat yang hidup saat ini terhadap SDH, agar tetap utuh untuk diberikan kepada generasi akan datang. Nilai-nilai ini tidak terefleksi dalam harga pasar (Bishop, 1999).

\section{B. Metode Penilaian Sumberdaya Hutan}

Penilaian sumberdaya hutan merupakan studi tentang metodologi dan konsep penentuan nilai dari sumberdaya hutan. Seperti telah dijelaskan di muka, langkah pertama untuk untuk memperoleh nilai dari sumberdaya hutan adalah dengan melakukan identifikasi terhadap berbagai jenis manfaat yang dihasilkan dari sumberdaya hutan. Keberadaan setiap jenis manfaat ini merupakan indikator adanya nilai yang menjadi sasaran penilaian. Setiap indikator nilai (komponen sumberdaya hutan) ini dapat berupa barang hasil hutan, jasa dari fungsi ekosistem hutan maupun atribut yang melekat pada hutan tersebut dalam hubungannya dengan sosial budaya masyarakat.

Langkah kedua dalam penilaian sumberdaya hutan ini adalah melakukan identifikasi kondisi biofisik hutan dan sosial budaya masyarakat karena proses pembentukan nilai sumberdaya hutan berdasarkan pada persepsi individu/masyarakat dan kualitas serta kuantitas komponen sumberdaya hutan tersebut. Langkah selanjutnya adalah melakukan penilaian sumberdaya hutan melalui proses penilaian biofisik dan sosial budaya yaitu kuantifikasi setiap indikator nilai berupa barang hasil hutan, jasa fungsi ekosistem hutan serta atribut hutan dalam kaitannya dengan budaya setempat. Atas dasar kuantifikasi indikator nilai tersebut dilakukan penilaian ekonomi manfaat hutan, berdasarkan metode penilaian tertentu pada setiap klasifikasi nilai (Bahruni, 1999).

Metode penilaian manfaat hutan pada dasarnya dibagi dalam dua kelompok yaitu metode atas dasar pasar dan metode pendekatan terhadap pasar yaitu pendekatan terhadap kesediaan membayar. Metode pendekatan terhadap pasar ini oleh beberapa ahli ekonomi telah dikembangkan dan diaplikasikan untuk menilai manfaat hutan yang tidak memiliki harga pasar dalam satuan moneter. Metode ini mencoba untuk menggambarkan permintaan konsumen, sebagai contoh kesediaan membayar konsumen 
(willingness to pay-WTP) terhadap manfaat hutan yang tidak memiliki harga pasar dalam satuan moneter, atau kesediaan menerima konsumen (willingness to accept WTA) terhadap kompensasi yang diberikan kepada konsumen untuk manfaat yang hilang dalam satuan moneter.

Bishop (1999) membagi metode penilaian ekonomi untuk manfaat yang diperoleh dari sumber daya alam dan lingkungan menjadi lima kelompok :

(i) Penilaian berdasarkan harga pasar, termasuk pendugaan manfaat dari kegiatan produksi dan konsumsi dalam kehidupan sehari-hari.

Barang dan jasa yang dihasilkan hutan dan diperdagangkan (memiliki harga pasar) diantaranya adalah hasil hutan kayu, produk hasil hutan non kayu seperti pangan, tumbuhan obat, hidupan liar dan rekreasi. Untuk produk-produk tersebut, harga pasar dapat digunakan untuk menggambarkan perhitungan finansial, untuk membandingkan antara manfaat dan biaya dari berbagai alternatif pilihan penggunaan lahan hutan. Harga pasar diturunkan melalui interaksi antara produsen dan konsumen melalui permintaan dan penyediaan barang dan jasa (transaksi pasar). Dalam pasar yang efisien (Pasar Persaingan Sempurna) harga barang dan jasa mencerminkan kesediaan membayar setiap orang (WTP). Nilai yang diperoleh dari pasar persaingan sempurna merupakan nilai baku karena memenuhi keinginan penjual dan pembeli serta memberikan surplus kesejahteraan yang maksimal. Apabila memungkinkan harga pada pasar yang efisien ini menjadi pilihan pertama untuk membandingkan manfaat dan biaya dari berbagai kegiatan.

(ii) Pendekatan harga pengganti, termasuk metode biaya perjalanan, hedonic price, dan pendekatan barang pengganti.

Metode ini berdasarkan pada kenyataan bahwa nilai sumberdaya hutan yang tidak memiliki harga pasar dapat tergambarkan secara tidak langsung pada pengeluaran konsumen, harga barang dan jasa yang diperjualbelikan, atau dalam tingkat produktivitas dari kegiatan pasar tertentu. Metode ini terdiri atas :

a. Metode Biaya Perjalanan

Metode ini berdasarkan pada asumsi bahwa konsumen menilai tempat rekreasi hutan berdasarkan pada biaya yang dikeluarkan untuk dapat sampai ke tempat tujuan (wisata hutan), termasuk biaya perjalanan sebagai biaya oportunitas dari waktu yang dikeluarkan untuk melakukan perjalanan ke tempat wisata hutan. Tiga tahapan dasar dalam metode ini adalah : (1) melaksanakan survey terhadap beberapa pengunjung sebagai contoh, untuk mengetahui biaya perjalanan yang dikeluarkan untuk sampai ke tempat wisata. Biaya perjalanan ini termasuk waktu perjalanan, berbagai pengeluaran (cash) selama perjalanan menuju ke tempat wisata hutan sampai dengan kembali ke tempat asal termasuk tiket masuk, biaya parkir dan lain-lain. Tambahan informasi yang dibutuhkan adalah asal pengunjung, faktor sosial ekonomi pengunjung seperti pendidikan dan pendapatan, (2) mengolah data yang diperoleh untuk menyusun persamaan matematis permintaan pengunjung atas tempat wisata hutan, (3) menghitung nilai tempat wisata bila terdapat perubahan atas kondisi lingkungan. Pada langkah ini perlu diketahui kesediaan membayar konsumen terhadap adanya perubahan kondisi tempat wisata. Dalam perkembangannya, survey untuk metode biaya perjalanan ini dapat dikombinasikan dengan survey untuk metode penilaian kontingensi sebagai estimasi untuk melakukan penilaian atas nilai pilihan dan nilai bukan guna hutan. 


\section{b. Harga Hedonik}

Metode harga hedonik menekankan pada pengukuran manfaat lingkungan yang melekat pada barang atau jasa yang memiliki harga pasar. Metode ini didasarkan pada gagasan bahwa barang pasar menyediakan pembeli dengan sejumlah jasa, yang beberapa diantaranya bisa merupakan kualitas lingkungan. Penerapan umum teknik penilaian ini adalah pada pendekatan nilai properti dan pendekatan perbedaan upah. Penerapan pendekatan harga hedonik ini terhadap nilai properti (bangunan) meliputi pengamatan terhadap unsur-unsur yang mempengaruhi nilai properti yaitu lokasi dan pengaruh kualitas lingkungan. Sebagai contoh nilai pasar perumahan, tergantung dari berbagai faktor diantaranya adalah luas bangunan, lokasi, material yang digunakan, dan kualitas lingkungan sekitarnya. Sehingga bangunan rumah dengan kualitas udara segar di sekitarnya, akan membuat orang bersedia membayar lebih mahal dibandingkan rumah dengan kualitas sama tetapi berada pada lingkungan yang jelek. Metode ini telah digunakan di negara berkembang untuk mengestimasi dampak negatif dari polusi udara dan kebisingan, atau mengestimasi dampak keberadaan fasilitas pengolah limbah dan juga dampak positif kedekatan dengan sumber air dan lahan hijau pada harga pasar perumahan.

c. Pendekatan Barang Subtitusi

Untuk produk-produk kehutanan yang tidak ada pasarnya atau langsung dimanfaatkan oleh pemungutnya (contoh : kayu bakar), nilai produk tersebut dapat diduga dari harga pasar produk-produk sejenis (contoh : kayu bakar yang dijual di daerah lain) atau nilai terbaik dari barang subtitusi atau barang alternatif (contoh : batubara). Untuk barang subtitusi yang tidak memiliki harga pasar, nilainya dapat diperkirakan dengan menghitung biaya oportunitas dari pemakaian sebagai barang subtitusi tersebut dalam dua tahap, yaitu : 1) mengestimasi faktor konversi untuk persamaan dua barang subtitusi, 2) mengestimasi pengaruh marjinal pada output, dan juga keuntungan, dari perubahan dalam penggunaan barang subtitusi.

(iii) Pendekatan fungsi produksi (dosis respon), dengan fokus pada hubungan biofisik antara fungsi hutan dan kegiatan pasar.

Metode penilaian ini sering disebut dengan teknik perubahan dalam produksi, metode input-output atau dosis respon atau pendekatan fungsi produksi. Metode ini menekankan pada hubungan antara kehidupan manusia (lebih sempitnya lagi pada pertambahan output dari barang dan jasa yang memiliki pasar) dan perubahan dari sumber daya alam baik kualitas maupun kuantitas (Maller, 1992). Pendekatan fungsi produksi dapat digunakan untuk mengestimasi nilai guna tidak langsung dari fungsi ekologis hutan, melalui kontribusi nilai guna tersebut terhadap kegiatan pasar. Terdapat dua tahapan prosedur dalam metode ini,yaitu : (1) menentukan pengaruh secara fisik dari perubahan lingkungan pada kegiatan ekonomi, (2) Menilai hasil perubahan lingkungan tersebut terhadap produksi dan konsumsi, biasanya menggunakan harga pasar. Metode ini telah banyak digunakan untuk mengestimasi dampak dari perubahan kualitas lingkungan (contoh : deforestasi, erosi, polusi udara dan air) terhadap produktivitas pertanian, kehutanan, dan perikanan, kesehatan manusia, dan biaya pemeliharaan infrastruktur ekonomi. Pendekatan fungsi produksi relatif sederhana pada kondisi single use system, yaitu pada kondisi dimana hanya terdapat satu fungsi ekologis dari nilai hutan. Pada kondisi multiple use systems yaitu bila terdapat lebih dari satu fungsi ekologis hutan sebagai nilai ekonomi hutan, maka penerapan metode ini lebih sulit, karena 
memungkinkan terjadinya double counting. Untuk itu, asumsi mengenai hubungan antara berbagai penggunaan harus dengan jelas ditentukan.

(iv) Pendekatan preferensi

Dalam pendekatan ini, informasi mengenai nilai manfaat lingkungan diperoleh dengan mengajukan pertanyaan kepada konsumen mengenai kesediaan membayar untuk manfaat lingkungan yang diterima, dan atau kesediaan menerima untuk menerima kompensasi atas manfaat lingkungan yang hilang. Teknik penilaian yang termasuk dalam pendekatan preferensi adalah :

\section{a. Penilaian Kontingensi}

Studi dengan metode ini banyak mengunakan data dari hasil survey. Format pertanyaan pada metode ini adalah pertanyaan terbuka dan pertanyaan menggunakan pilihan. Wawancara dilakukan dengan menanyakan WTA dan WTP terhadap SDA agar tetap terpelihara. CVM hanya dapat digunakan sebagai metode untuk mengestimasi nilai bukan guna yang tidak diperdagangkan di pasar, dan menilai barang yang tidak memiliki barang subtitusi, komplemen, dan pengganti yang diperdagangkan di pasar, contohnya nilai pilihan atau keberadaan suatu fungsi SDH. Untuk menghasilkan informasi yang akurat maka diperlukan beberapa hal, yaitu rancangan kuesioner yang tepat serta melakukan uji pendahuluan terhadap kuesioner tersebut, survey yang tepat dan teliti, serta perhitungan ekonometrika yang rumit untuk mendeteksi dan menganalisa data yang bias.

\section{b. Peringkat Kontingen}

Metode ini menggunakan pertanyaan terhadap responden untuk menentukan peringkat dan memberi skor dari beberapa barang yang tidak memiliki harga pasar. Pada beberapa kasus, nilai moneter dapat ditentukan secara tidak langsung, dengan memasukkan dalam peringkat kontingen satu atau lebih barang yang memiliki harga pasar sebagai “pengikat” (pembanding). Metode ini secara konsep sederhana, mudah untuk dicatat, dan dapat dihasilkan dugaan menyeluruh dari sejumlah barang dan jasa hutan, tanpa melaksanakan survey WTP secara terpisah untuk setiap nilai guna dan nilai bukan guna. Di sisi lain, metode ini kurang menghasilkan dugaan besarnya WTP yang akurat. Pertanyaan mendasar adalah apakah skor yang dihasilkan dari peringkat kontingen ini menggambarkan peringkat ordinal dari preferensi (pertama, kedua, ketiga, dst) sebagai lawan dari pengukuran kardinal (satu, dua, tiga, dst). Di samping itu, penggunaan harga/biaya yang memiliki harga pasar sebagai "pengikat" (pembanding) untuk memasukkan nilai moneter kepada barang dan jasa yang tidak memiliki harga pasar tidak valid, karena kedua barang tersebut berbeda proporsi penggunaannya.

\section{c. Percobaan Pilihan (Choice Experiments)}

Metode percobaan pilihan (CE) ini menggunakan pertanyaan pada responden untuk memilih diantara beberapa satuan barang yang tidak memiliki pasar, yang memiliki berbagai atribut. Di bidang kehutanan, dalam survey CE, responden disajikan berbagai alternatif landskap (dalam bentuk gambar), yang sangat beragam dalam hal jenis tumbuhan, keragaman umur, persentase lahan terbuka, jalan dan harga 
hipotetik. Kelebihan CE adalah kemampuan untuk mengestimasi nilai karakteristik dari produk lingkungan.

d. Metode Partisipatory

Metode ini menggunakan teknik "focus group" baik dalam pengumpulan data dan analisis sehingga diharapkan dapat mengurangi bias dan menghasilkan informasi yang lebih akurat. Teknik ini lebih baik dalam pengumpulan data kualitatif dibandingkan data kuantitatif.

(v) Pendekatan berdasarkan biaya, termasuk di dalamnya adalah biaya penggantian dan pengeluaran defensif.

Terdapat tiga alternatif metode yang menekankan pada biaya penyediaan, pemeliharaan, barang dan jasa lingkungan, yaitu :

a. Metode biaya penggantian, yang mengukur nilai lingkungan dengan menghitung biaya produksi ulang dari suatu manfaat.

Teknik berdasarkan biaya penggantian ini menghasilkan nilai untuk manfaat dari barang dan jasa dengan menduga biaya penggantian manfaat dengan alternatif barang dan jasa lainnya. Atau dengan kata lain metode ini berdasarkan pada biaya penggantian atau pemulihan asset yang mengalami degradasi. Penerapan teknik ini untuk menilai manfaat hutan, adalah dengan menduga nilai kehilangan nutrisi tanah sebagai akibat peningkatan erosi yang disebabkan oleh kegiatan penebangan dan deforestasi, dengan melalui penghitungan biaya pembuatan pupuk yang dibutuhkan untuk mengganti nutrisi yang hilang (Copra, 1993; Niskanen, 1998 dalam Bishop, 1999).

b. Metode biaya preventif, dengan mengestimasi biaya pencegahan degradasi lingkungan.

Metode ini menilai manfaat barang dan jasa lingkungan dengan mengestimasi biaya pencegahan berkurangnya manfaat lingkungan yang diperoleh dari suatu area. Pendekatan ini lebih tepat diterapkan untuk menilai nilai guna tidak langsung. Di bidang kehutanan, metode ini dapat digunakan untuk mengukur berkurangnya manfaat perlindungan DAS yang disebabkan oleh pembangunan jalan untuk kegiatan penebangan, dengan menghitung pertambahan biaya yang dibutuhkan untuk menerapkan metode penebangan yang tidak merusak lingkungan (Reduced Impact Logging). Perlu diingat bahwa manfaat dari biaya preventif ini harus sesuai dengan yang dihasilkan oleh manfaat lingkungan sebenarnya, untuk memperoleh dugaan biaya yang realistik. Pada metode ini memfokuskan pada biaya pencegahan kerusakan sebelum terjadinya kerusakan itu.

c. Pendekatan biaya oportunitas, yang mengestimasi biaya produksi (biaya pengadaan) sebagai biaya pengganti dari nilai manfaat yang tidak memiliki harga pasar.

Pada teknik penilaian ini menekankan faktor biaya pengadaan barang dan jasa hasil hutan khususnya biaya yang paling esensial yaitu upah. Biaya oportunitas dari waktu yang digunakan untuk memungut hasil hutan non kayu yang tidak memiliki harga pasar tersebut, selanjutnya dijadikan pengganti untuk nilai produk tersebut. Data yang dibutuhkan adalah jumlah waktu yang dibutuhkan untuk pemungutan tersebut, jumlah pungutan hasil hutan non kayu dan tingkat upah tenaga kerja di daerah pedalaman. 
Sementara itu James, R.F (1991) mengelompokkan teknik penilaian manfaat sumberdaya hutan berdasarkan kriteria yang menggambarkan karakteristik setiap jenis nilai, baik nilai guna langsung, nilai guna tidak langsung, nilai pilihan dan nilai keberadaan. Untuk metode penilaian nilai guna langsung terdiri atas :

(i) Nilai manfaat sosial bersih

Metode ini menggunakan data demand dan supply yang lengkap secara series sehingga dapat disusun kurva supply dan demand untuk menentukan nilai barang berdasarkan perpotongan kedua kurva tadi sebagai harga keseimbangan.

(ii) Harga pasar

Metode ini digunakan untuk barang atau jasa hutan yang memiliki harga pasar. Data yang diperlukan adalah harga dan jumlah setiap jenis barang/jasa hutan. Menurut Davis dan Johnson (1983) metode fakta pasar dan nilai kini bersih termasuk dalam teknik penilaian ini. Metode nilai kini bersih mencoba untuk menghitung nilai saat ini dari hasil penggunaan lahan hutan.

(iii) Harga pengganti

Metode ini terdiri dari beberapa teknik :

a. Harga subtitusi. Nilai barang/jasa hutan yang tidak memiliki harga pasar didekati dari harga barang subtitusinya.

b. Harga subtitusi tidak langsung. Untuk barang subtitusi yang tidak ada harga pasarnya, maka nilai barang didekati dari harga penggunaan lain dari barang subtitusi.

c. Biaya oportunitas tidak langsung. Nilai barang/jasa hutan didekati dari faktor biaya pengadaannya (khususnya upah).

d. Nilai tukar perdagangan. Harga barang/jasa hutan didekati dari nilai pertukaran dengan barang yang ada harganya.

e. Biaya relokasi. Nilai barang/jasa hutan didekati dari biaya pemindahan ke tempat lain dimana manfaat penggunaan dapat digantikan di tempat baru.

(iv) Biaya perjalanan.

Metode ini biasa digunakan untuk menghitung nilai kawasan rekreasi hutan. Modifikasi dari metode ini adalah biaya pengadaan yang bisa digunakan untuk menghitung nilai air berdasarkan biaya besarnya biaya pengadaan sampai air tersebut dikonsumsi (Bahruni, 1999).

(v) Nilai dalam proses produksi

Teknik ini digunakan untuk menilai barang/jasa hutan yang merupakan input dalam produksi suatu barang. Sebagai contoh untuk menghitung nilai tegakan melalui pendekatan output kayu gergajian yang dihasilkan.

Untuk memilih metode penilaian nilai guna langsung dari sumberdaya hutan yang tepat ditentukan berdasarkan pada seberapa jauh ketersediaan data harga yang ada dan sifat dari produk hutan tersebut. Tahapan pemilihan metode penilaian guna langsung dapat dilihat pada gambar 1. 


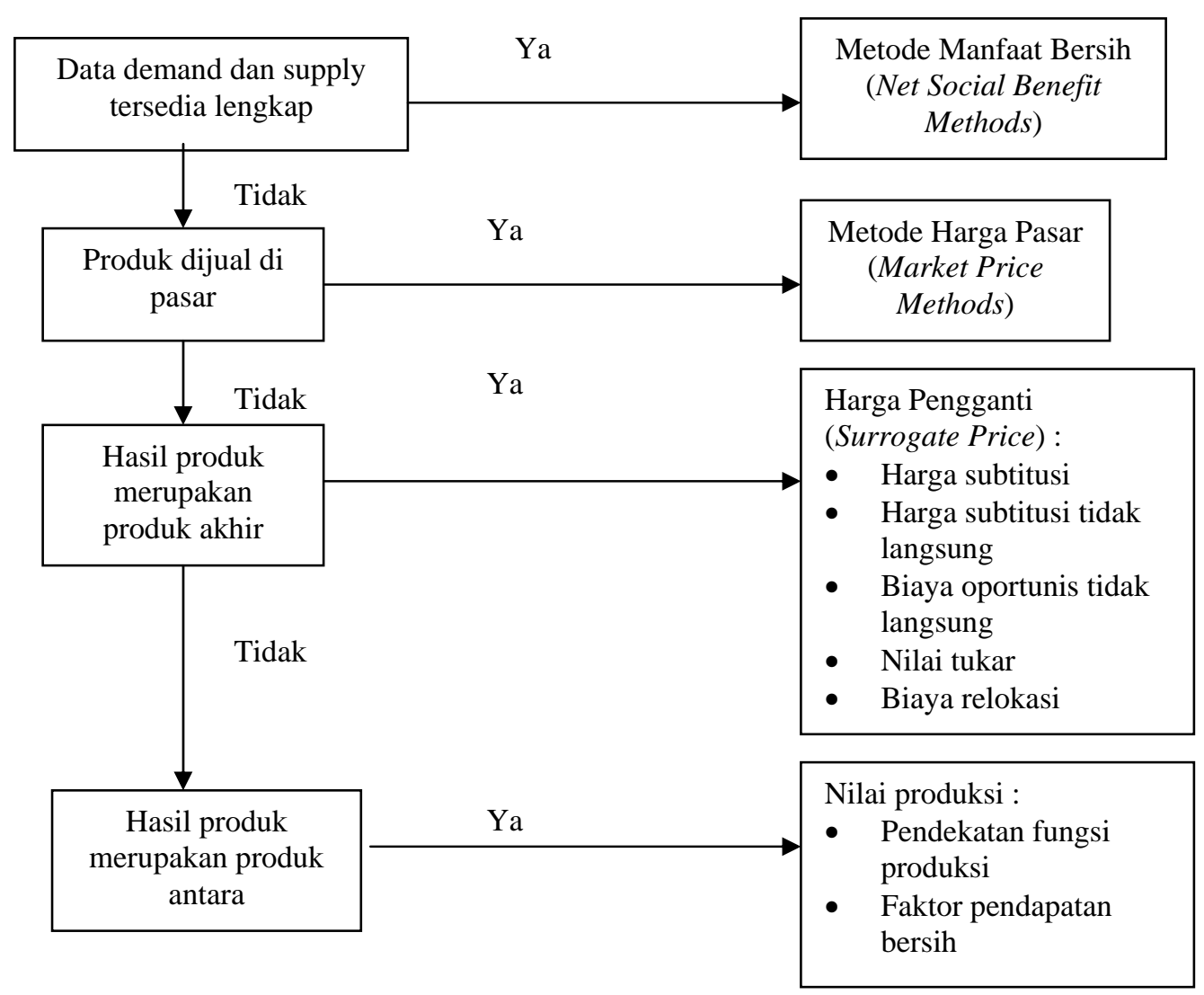

Gambar 2. Tahapan pemilihan metode penilaian nilai guna langsung (James, 1991). Figure 2. Selection steps of valuation method for direct use value (James, 1991).

Sedangkan untuk metode penilaian nilai guna tidak langsung, nilai pilihan dan nilai keberadaan dari sumberdaya hutan terdiri atas :

(i) Perlindungan asset

a. Biaya penggantian. Nilai dari fungsi sumberdaya didekati dari biaya penggantian/pembuatan kembali sumberdaya hutan yang rusak, sehingga fungsinya terpulihkan kembali atau berdasarkan biaya penggantian fungsi sumberdaya hutan yang rusak dengan alternatif barang/jasa lainnya.

b. Biaya rehabilitasi. Nilai dari fungsi sumberdaya hutan didekati dari biaya perbaikan kondisi sumberdaya tersebut sehingga fungsinya kembali seperti semula. Perbedaan dengan biaya penggantian adalah tingkat kerusakan yang terjasi tidak sampai harus mengganti total aset tersebut.

c. Nilai produksi yang hilang. Nilai dari fungsi sumberdaya didekati dari nilai perubahan hasil produksi akibat perubahan fungsi sumberdaya tersebut.

d. Biaya pembangunan tambahan. Nilai dari fungsi sumberdaya hutan didekati dari pengeluaran biaya tambahan pembuatan fasilitas tertentu agar fungsi SDH tetap ada.

(ii) Metode penilaian kontingensi.

Pemilihan metode penilaian nilai guna tidak langsung, nilai pilihan dan nilai keberadaan ditentukan berdasarkan pada dapat tidaknya nilai tersebut direfleksikan pada nilai-nilai manfaat yang mudah terukur. Tahapan pemilihannya dapat dilihat pada gambar 3. 


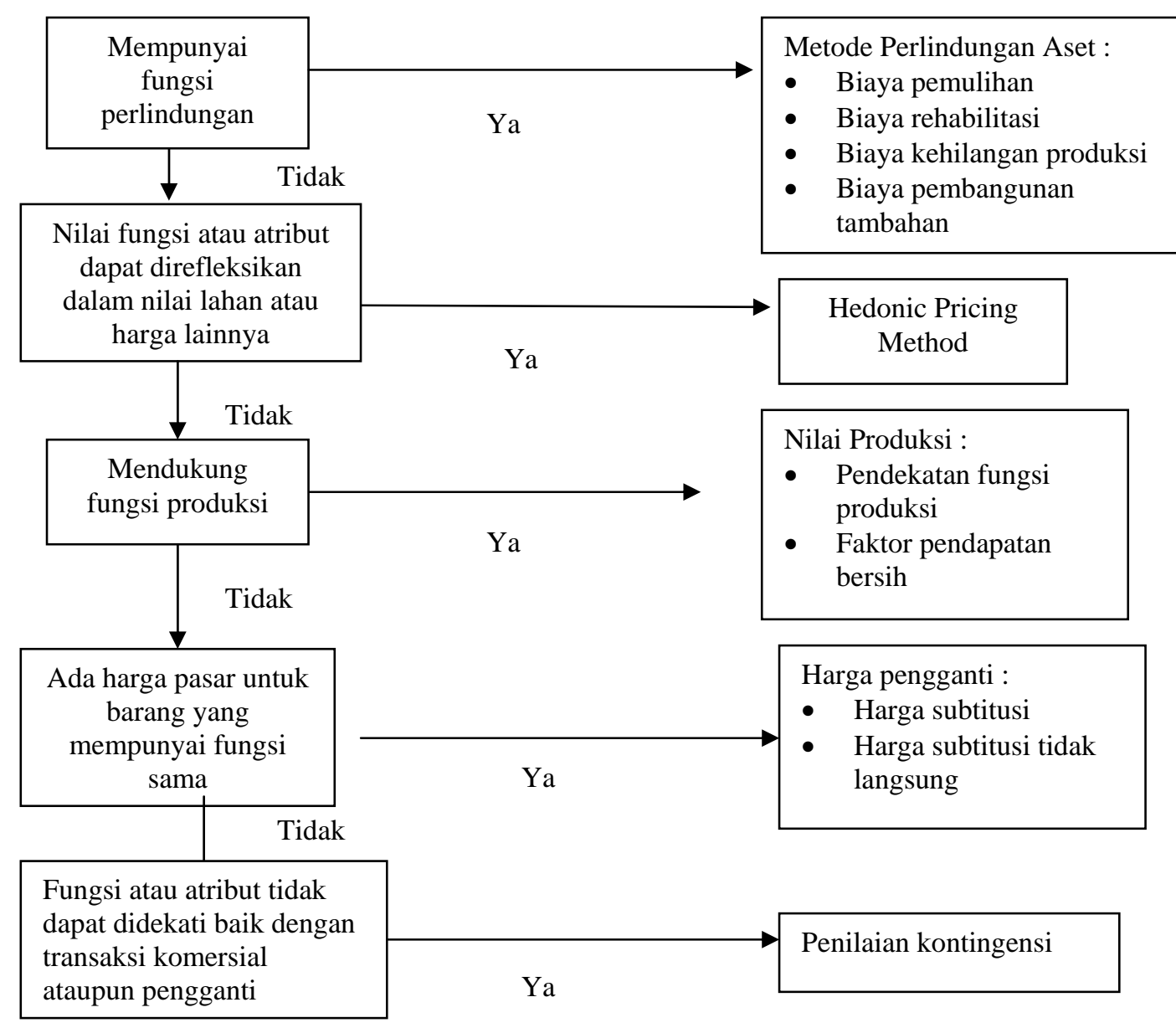

Gambar 3. Tahapan pemilihan metode penilaian nilai guna langsung, nilai pilihan, dan nilai keberadaan (James, 1991).

Figure 3. Selection steps of valuation method for indirect use value, option value and existence value (James, 1991).

Pearce and Turner (1990) membagi metode penilaian ekonomi SDA berdasarkan dua pendekatan kurva (Gambar 4) : (1) pendekatan yang mengacu pada kurva permintaan (Marshallian dan Hicksian), dan (2) pendekatan yang mengacu pada pendekatan non kurva permintaan. Pendekatan yang mengacu pada kurva permintaan dapat dibagi menjadi dua : (a) permintaan diukur dengan menyelidiki preferensi individu terhadap SDA (melalui kuesioner), (b) permintaan dinyatakan dengan menyelidiki pembayaran individu terhadap SDA melalui pasar, yang berkaitan dengan SDA yang dinikmati. Kurva permintaan Marshall mengukur kesejahteraan melalui surplus konsumen, sedangkan kurva permintaan Hicksian mengukur kesejahteraan melalui kompensasi pendapatan. 


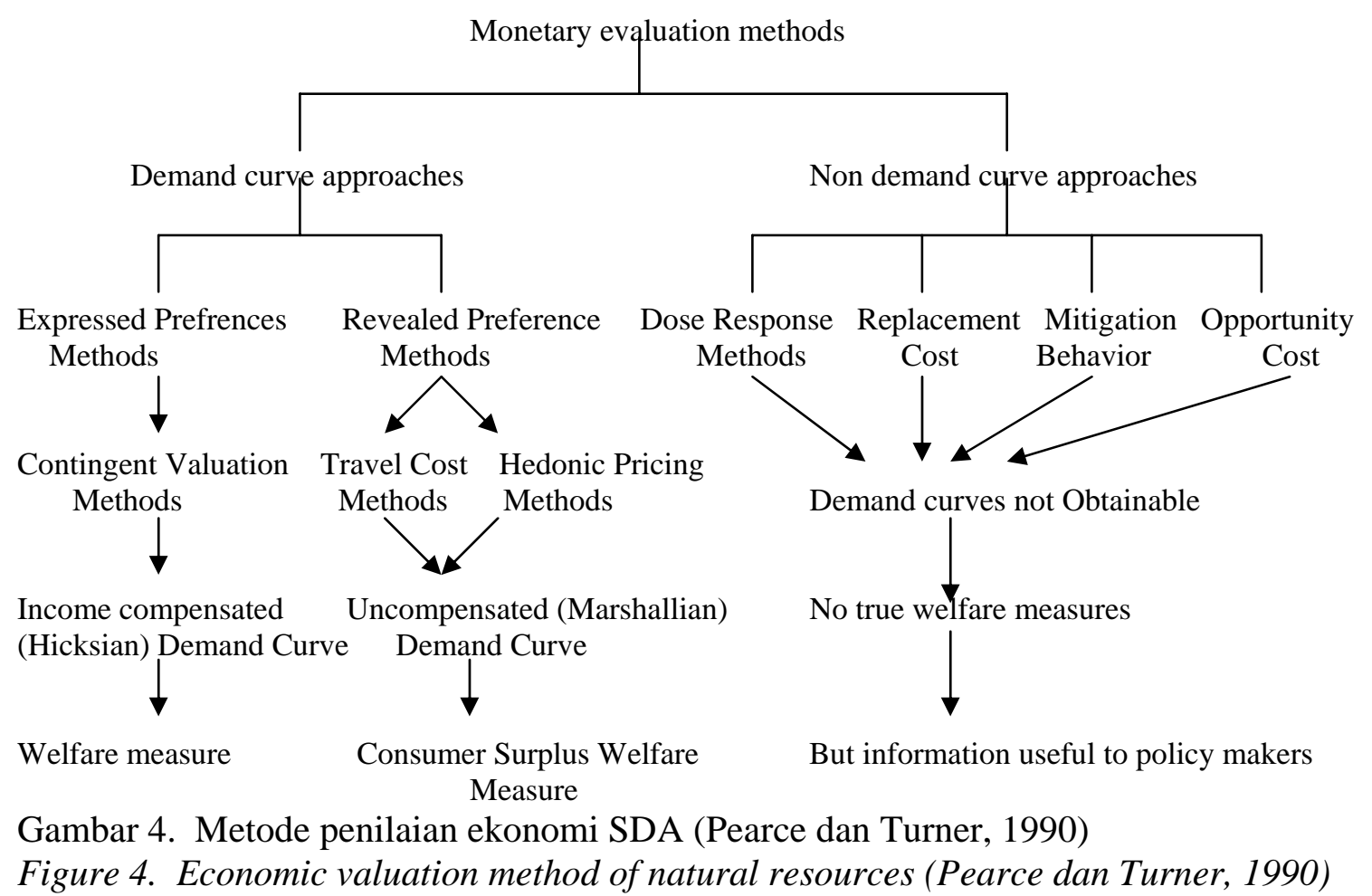

Pendekatan di atas memiliki kesamaan dengan pendekatan penilaian ekonomi SDA yang dikemukakan oleh Pearce dan Moran (1994) sebagai berikut :

- Pendekatan langsung : usaha untuk menentukan preferensi konsumen secara langsung dengan menggunakan teknik survei atau eksperimen

- Pendekatan tidak langsung : teknik untuk menentukan preferensi konsumen aktual dengan berdasarkan pada informasi dari hasil observasi pasar.Preferensi pada barang-barang lingkungan secara tidak langsung dinyatakan pada saat individu membayar barang-barang yang dipasarkan.

Hoevennagel (1994) dalam Yakin (1997) telah menganalisis dan membandingkan metode-metode penilaian ekonomi sumberdaya hutan berdasarkan dua kriteria utama yaitu kemampuan penerapannya secara teknis (technical aplicability) dan kemampuan praktisnya (practical aplicability). Kemampuan secara teknis diukur dengan dua parameter utama yaitu validitas dan reliabilitas dan kelengkapan cakupannya (comprehensiveness). Kemampuan praktis diukur dengan parameter kelengkapan (completeness) dan kemampuan penerapannya. Perbandingan antar metode valuasi ekonomi dapat dilihat pada tabel 5. Setelah dilakukan kajian komparasi, maka dapat disimpulkan bahwa : (1) tidak ada satu teknikpun yang superior terhadap yang lain; (2) masing-masing teknik adalah cocok bagi beberapa kasus-kasus tertentu tetapi tidak pada kasus lainnya; (3) penentuan teknik yang akan digunakan tergantung pada masalah apa yang akan dinilai serta sumberdaya pendukung studi.

Tabel 1. Perbandingan antara berbagai metode valuasi ekonomi 
Table 1. Comparison between some economic valuation methods

\begin{tabular}{|l|c|c|c|c|}
\hline \multirow{2}{*}{$\begin{array}{l}\text { Metode } \\
\text { valuasi }\end{array}$} & Validitas & Reliabilitas & Kekomprehensifan & $\begin{array}{c}\text { Kelengkapan } \\
\text { Kepraktisan }\end{array}$ \\
\cline { 2 - 5 } $\begin{array}{l}\text { Metode dosis } \\
\text { repon }\end{array}$ & 0 & -- & + \\
\hline $\begin{array}{l}\text { Metode harga } \\
\text { hedonik }\end{array}$ & 0 & 0 & - & 0 \\
\hline $\begin{array}{l}\text { Metode biaya } \\
\text { perjalanan }\end{array}$ & 0 & 0 & - & 0 \\
\hline $\begin{array}{l}\text { Metode } \\
\text { perilaku } \\
\text { mencegah }\end{array}$ & 0 & 0 & - & 0 \\
\hline $\begin{array}{l}\text { Metode } \\
\text { valuasi } \\
\text { kontingensi }\end{array}$ & 0 & ++ & ++ & + \\
\hline
\end{tabular}

Keterangan : 0 = kategori sedang, -- = sangat rendah, - = rendah, $+=$ tinggi, $++=$ sangat tinggi (Hoevenagel, 1994 dalam Yakin, 1997).

\section{Hasil-hasil Penelitian Terdahulu}

Beberapa literatur telah memuat beberapa hasil penelitian mengenai nilai ekonomi lingkungan khususnya sebagai dampak dari kegiatan rehabilitasi hutan dan lahan. Niskanen (1998) dalam penelitiannya mengenai nilai eksternal lingkungan sebagai dampak dari reforestasi di Thailand, menghitung manfaat ekonomi dari lingkungan dalam hal penyerapan karbon dan peningkatan fungsi perlindungan terhadap erosi serta menghitung biaya ekonomi lingkungan dalam hal konsumsi air oleh tanaman dalam proses transpirasi dan kehilangan nutrisi tanah pada kegiatan pemanenan, dari beberapa pilihan kegiatan reforestasi yang paling banyak digunakan di Thailand. Dari hasil penelitian diperoleh bahwa nilai ekonomi total terbesar dari dampak lingkungan akibat reforestasi dihasilkan oleh kegiatan reforestasi yang diusahakan secara private yaitu untuk kepentingan industri dengan jenis tanaman Eucalyptus camaldulensia yang menghasilkan nilai kini bersih dari dampak lingkungan pengusahaan Eucalyptus camaldulensia sebesar 19.129 Thai Bath/ha atau setara dengan US \$ 765,16/ha dengan tingkat suku bunga sebesar $10 \%$.

Untuk memperoleh gambaran lebih mendalam mengenai penerapan konsep nilai ekonomi total, dapat dilihat pada hasil studi Kramer, Narendra Sharma dan Mohan Munasinghe (1995) mengenai nilai ekonomi lingkungan dari kegiatan pembangunan dan konservasi hutan di Madagaskar. Studi yang dilakukan Kramer et.al ini bertujuan untuk menerapkan beberapa metode penilaian untuk digunakan dalam analisis ekonomi dari suatu proyek konservasi hutan. Hasil studi beserta metode penilaian yang digunakan dapat dilihat pada tabel 2. 
Tabel 2. Hasil studi penilaian ekonomi total di Taman Nasional Mantadia, Madagaskar. Table 2. Study results of total economic valuation in Mantadia, Madagaskar National Park

\begin{tabular}{|c|c|c|c|}
\hline No & Nilai yang Dihitung & Teknik Penilaian & $\begin{array}{l}\text { Dugaan Nilai Kini } \\
\text { Bersih (NPV) }\end{array}$ \\
\hline 1 & $\begin{array}{l}\text { Nilai guna langsung untuk } \\
\text { masyarakat lokal (hasil } \\
\text { hutan kayu dan non kayu, } \\
\text { hasil pertanian) }\end{array}$ & $\begin{array}{l}\text { Harga pasar untuk } \\
\text { menduga aliran kas dari } \\
\text { hasil pengusahaan hasil } \\
\text { hutan kayu dan non kayu, } \\
\text { dan dari hasil perladangan } \\
\text { berpindah }\end{array}$ & $\begin{array}{l}\text { US \$ } 566.000 \text { atau } \\
\text { US } \$ 91 / \text { rumah } \\
\text { tangga/tahun. } \\
\text { (selama } 20 \text { tahun, } \\
\text { menggunakan } \\
\text { tingkat suku bunga } \\
10 \% \text { ) }\end{array}$ \\
\hline 2 & $\begin{array}{l}\text { Nilai guna langsung dan } \\
\text { nilai non guna untuk } \\
\text { masyarakat lokal }\end{array}$ & $\begin{array}{l}\text { Metode kontingensi untuk } \\
\text { menduga kesediaan } \\
\text { menerima kompensasi } \\
\text { untuk hilangnya akses ke } \\
\text { dalam hutan. }\end{array}$ & $\begin{array}{l}\text { US \$ } 673.000 \text { atau } \\
\text { US \$ } 108 \text { (selama } 20 \\
\text { tahun, menggunakan } \\
\text { tingkat suku bunga } \\
10 \% \text { ) }\end{array}$ \\
\hline 3 & $\begin{array}{l}\text { Nilai guna tidak langsung } \\
\text { untuk petani di hilir } \\
\text { (kontrol banjir) }\end{array}$ & $\begin{array}{l}\text { Pendekatan } \\
\text { produksi untuk menduga } \\
\text { hilangnya produksi padi } \\
\text { akibat banjir yang } \\
\text { disebabkan oleh deforestasi }\end{array}$ & US \$ 71.000 \\
\hline 4 & $\begin{array}{l}\text { Nilai guna langsung untuk } \\
\text { turis internasional } \\
\text { (rekreasi) }\end{array}$ & $\begin{array}{l}\text { Metode biaya perjalanan } \\
\text { untuk menduga surplus } \\
\text { konsumen dari turis }\end{array}$ & $\begin{array}{l}\text { US \$ 936.000 } \\
\text { menggunakan model } \\
\text { kegunaan acak; US \$ } \\
1.7 \quad \text { juta } \\
\text { menggunakan model } \\
\text { perjalanan typical } \\
\text { (suku bunga } 10 \%)\end{array}$ \\
\hline 5 & $\begin{array}{l}\text { Nilai guna langsung untuk } \\
\text { turis internasional } \\
\text { (rekreasi }\end{array}$ & $\begin{array}{l}\text { Metode kontingensi untuk } \\
\text { menduga kesediaan } \\
\text { membayar para turis untuk } \\
\text { berkunjung ke Taman } \\
\text { Nasional Mantadia }\end{array}$ & US \$ 2.53 juta \\
\hline 6 & $\begin{array}{l}\text { Nilai bukan guna untuk } \\
\text { warga negara Amerika } \\
\text { Serikat (konservasi hutan } \\
\text { hujan) }\end{array}$ & $\begin{array}{lr}\text { Metode kontingensi untuk } \\
\text { menduga } & \text { kesediaan } \\
\text { membayar } & \text { untuk } \\
\text { perlindungan hutan tropiss } \\
\text { di seluruh dunia (45 juta } \\
\text { ha) }\end{array}$ & US \$ 1 miliar \\
\hline
\end{tabular}

Sumber : Kramer et.al (1995). 


\section{PENUTUP}

Konsep nilai ekonomi total dan metode penilaian ekonomi mencoba untuk memberikan "nilai" terhadap seluruh manfaat yang dihasilkan hutan baik yang bersifat diperdagangkan dan memiliki harga pasar maupun yang tidak memiliki harga pasar. Hal tersebut sangat dibutuhkan mengingat masalah yang timbul pada saat pengambil kebijakan berusaha untuk menyeimbangkan antara dua tujuan dalam pengelolaan hutan yaitu manfaat produksi dan manfaat lingkungan, membutuhkan suatu dasar dan rekomendasi untuk menentukan alokasi sumberdaya alam yang adil.

Teknik penilaian ekonomi, khususnya untuk penilaian manfaat barang dan jasa hasil hutan non kayu yang tidak memiliki harga pasar dalam satuan moneter ini, sangat membantu dalam perumusan kebijakan pengelolaan hutan dan sistem pengelolaan hutan. Karakteristik manfaat hutan yang spesifik ini membutuhkan pendekatan teknik penilaian yang berbeda dengan manfaat hutan yang memiliki harga pasar dan diperdagangkan. Terakhir, dengan diketahuinya nilai ekonomi total dari sumberdaya hutan, diharapkan akan menciptakan pemanfaatan sumberdaya hutan yang lebih efisien karena manfaat hutan telah diperhitungkan secara memuaskan dalam perhitungan ekonomis. 


\section{DAFTAR PUSTAKA}

Bahruni. 1999. Diktat Penilaian Sumberdaya Hutan dan Lingkungan. Fakultas Kehutanan, Institut Pertanian Bogor. Bogor.

Bishop, J.T. 1999. Valuing Forests : A Review of Methods and Applications in Developing Countries. International Institute for Environment and Development. London.

Davis, L.S dan Johnson K.N. 1987. Forest Management $3{ }^{\text {rd }}$ Edition. Mc Graw-Hill Book Company. New York.

Hufschmidt, M.M et al. 1987. Lingkungan, Sistem Alami, dan Pembangunan : Pedoman Penilaian Ekonomis. Reksohadiprodjo S, penerjemah. Gajah Mada University Press. Yogyakarta. Terjemahan dari: Environmental, Natural Systems, and Development, An Economic Valuation Guide.

James, R.F. 1991. Wetland Valuation : Guidelines and Techniques. Asian Wetland Bureau-Indonesia. Bogor.

Kramer, R.A, Sharma, N, Munasinghe, M. 1995. Valuing Tropical Forests : Methodology and Case Study of Madagascar. World Bank Environment Paper Number 13. The World Bank. Washington D C.

Munasinghe, M. 1993. Environmental Economics and Sustainable Development. The World Bank. Washington DC.

Niskanen, A. 1997. Value of External Environmental Impacts of Reforestation in Thailand. Ecological Economics Journal No.26 (1998) pp 287 -297.

Pearce, D.W, Turner, R.K. 1990. Economics of Natural Resources and The Environment. Harvester Wheatsheaf. London.

Pearce, D. 1992. Economic Valuation and The Natural world. World Bank Working Papers. The World Bank. New York.

Pearce, D, Warford, J.J. 1993. World Without End : Economics, Environment, and Sustainable Development. Oxford University Press. New York.

Ramdan, H., Yusran, D. Darusman, 2003. Pengelolaan Sumberdaya Alam dan Otonomi Daerah. Alqaprint Jatinangor. Bandung.

Yakin, A. 1997. Ekonomi Sumberdaya dan Lingkungan: Teori dan Kebijaksanaan Pembangunan Berkelanjutan. Akademika Pressindo. Jakarta. 